International Journal of Social Science And Human Research

ISSN(print): 2644-0679, ISSN(online): 2644-0695

Volume 05 Issue 02 February 2022

DOI: $10.47191 /$ ijsshr/v5-i2-05, Impact factor-5.586

Page No: 409-417

\title{
Implementation of Hidden Curriculum in Online Learning at PKVM Al Ishlah Central Jakarta, Indonesia
}

\author{
Karnadi $^{1}$, Durotul Yatimah ${ }^{2}$, Eliana Sari ${ }^{3}$ \\ ${ }^{1,2}$ Community Education Study Program, Postgraduate Program - State University of Jakarta, Jakarta, Indonesia \\ ${ }^{3}$ Education Management Study Program, Postgraduate Program - State University of Jakarta, Jakarta, Indonesia
}

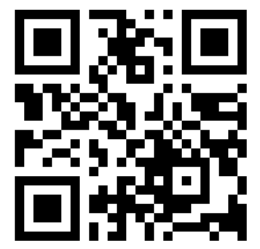

\begin{abstract}
The main quality of a nation is mainly determined by the quality of its education. The national education system according to Law No. 20 of 2003 includes formal education, non-formal education and informal education. Equality education is a non-formal education unit with the same graduate competency standards as formal schools. During the COVID-19 pandemic, all learning pathways for education are carried out online. The problem is that not all educators have optimal readiness to carry out online learning, both in methods and media assistance, so every educator is required to be able to find the right form of online learning to implement the formal curriculum and at the same time a hidden curriculum to develop the knowledge, skills and mental character of the participants educate.

This research was conducted on Equality Education at PKBM Al Ishlah, Central Jakarta with descriptive methods and qualitative approaches. Data collection techniques are interviews, observation and documentation. Data analysis was carried out on the implementation of the hidden curriculum at the preliminary stage, core activities, and closing activities of online learning. Based on the results of the study, character building in the preliminary activities of educators at PKBM Al Ishlah Central Jakarta has instilled religious character values, discipline, politeness, social care, and participation. In the core activities, educators instill values of independence, cooperation, care for the environment, and self-confidence. At the end of the lesson, educators instill the character values of critical thinking, honesty, responsibility, and religion.
\end{abstract}

KEYWORD: Covid-19, online learning, hidden curriculum, character

\section{INTRODUCTION}

National Education System in Law no. 20 of 2003 states that the national education system includes 3 channels of education, namely formal education, non-formal education and informal education. Formal education is a structured and tiered educational path consisting of basic education, secondary education, and higher education. Non-formal education is an educational path outside formal education that can be carried out in a structured and tiered manner. Informal education is the path of family and environmental education. One form of non-formal education program is equality education.

Equality education according to Zulkifli Agus Piliang (http://arifsulistyo.wordpress.com/jurusan-pls/kejar-paket-c/, accessed on January 5, 2021) is a non-formal education pathway with the same graduate competency standards as formal schools. However, the content, context, methodology, and approach to achieving graduate competency standards provide more applied, thematic, inductive concepts related to environmental issues and practice work-oriented or self-employed life skills. Thus, equality education is one of the non-formal education programs that are structured and assessed. One of the equality education programs is the Kejar Package $\mathrm{C}$ program which is equivalent to high school. Online learning is in accordance with government policy through the Ministry of Education and Culture through policy No. 36962/MPK.A/HK/2020 which decided to replace the face-toface learning process in both formal and non-formal education into an online learning process in all education units.

Achieving the quality of equality education is determined by a quality curriculum. The unit-level curriculum for the Equality Education Package C Program was developed based on the principles: life-centered, diverse and integrated, responsive to developments in science, technology and art, comprehensive and continuous, and the principles of lifelong learning. This means that the equivalence education curriculum of the Package $\mathrm{C}$ program contains more applied, thematic and life skills oriented concepts. The equivalence education curriculum in this case includes a written curriculum (written curriculum) and a hidden curriculum (hidden curriculum) that must be realized in the process of implementing learning.

The problem is that the learning process carried out so far refers to a formal curriculum that does not fully contain experiences that can form strong and positive characters in students. The application of a hidden curriculum which is theoretically very rational 


\section{Implementation of Hidden Curriculum in Online Learning at PKVM Al Ishlah Central Jakarta}

affects students in recognizing well the school environment, classroom atmosphere, and even broad school policies and management both in vertical and horizontal relationships (Dakir, 2010). Hidden curriculum has a considerable influence in building the internalization of the values and character of students in the PKBM environment. According to Gattron in Caswita (2013: 46), hidden curriculum is a curriculum that is not a part that must be studied, which is described as aspects that exist in PKBM outside the written curriculum, but are able to influence changes in values, perceptions, and behavior of students in learning. comply with PKBM regulations, carry out religious rules or events and comply with other regulations.

However, in general, educators do not know that the hidden curriculum is very important to implement in learning, they only pay attention to the core curriculum. The absorption of material by students is strongly influenced by the hidden curriculum because educators can translate social and moral messages through attitudes without realizing it. Strong character shapes individuals to become agents of change in themselves and the surrounding community. From the implementation of the hidden curriculum, positive habits will be formed in students which radiate through religious character, discipline, clean culture, good manners, and helping each other with friends (Suryaningtyas, 2014: 6-9). Students are generally very easy to absorb information or knowledge, but not infrequently because they are so fun playing gadgets, students become vulnerable to instant thinking, individualistic, not independent, and do not respect diversity. In fact, students are expected to become individuals with independent, tolerant, responsible, hard-working, and intelligent character, which is one of the main assets in facing the Industrial Revolution 4.0. Character education is important to build moral education progress in society. Salahudin and Alkrienciechie (2013: 42) explain that character is a characteristic of a person or group of people that contains values, abilities, moral capacity, and persistence in facing difficulties and challenges. Character education for students needs to be directed at the concept of learning to hone activities of reasoning and argumentation, to build the foundation of intelligence, independent attitude and not anti-diversity.

Character education for students needs to be done through habituation. Kurniawan (2017: 29) reveals that a person's character is formed from the habits he does, both attitudes and words that he often does to others. Meanwhile, according to Wibowo (2013:12) character is a natural trait of the human soul that characterizes a person in acting and interacting in family and society. The notion of character is also expressed by Samani and Hariyanto (2013: 41) as something that is typical of a person as a way of thinking and behavior to live and work together in relation to others who can make decisions and be responsible for their actions. But in fact, these things tend not to be the main focus of education in today's information age, because the ability to think critically, solve problems, and reconcile students' problems is minimal.

The purpose of learning activities is not only so that students are able to memorize the material, but also to be able to memorize and at the same time have literacy character skills with reasoning that is able to digest, analyze, and convey it well. This is a challenge that needs to be the focus of character education today. The implementation of online learning is still colored by several problems. Saepuloh (2020) explains that the existence of educators cannot be replaced by the internet, even though the work of delivering learning materials can be replaced with technology, but the inner approach and character formation and spiritual habituation by teachers cannot be replaced. Even according to Sri Rahayu (2020), with online learning the teacher's role is relatively limited to preparing learning materials, teaching and evaluating learning only, while the tasks of forming the character of students are replaced by parents in guiding children's regularity, learning discipline, and even being a facilitator who good for their children to study at home.

Other disadvantages of using online and its relation to character building include:

(http://repo.iaintulungagung.ac.id/21427/7/BAB\%20II.pdf)

a. Lack of interaction between teachers and students or even between students themselves, can slow down the formation of values in the teaching and learning process.

b. Tendency to ignore academic or social aspects and instead encourage business or commercial aspects.

c. The process of learning and teaching tends towards training rather than education.

d. The teacher's role has changed from previously mastering conventional learning techniques, but now teachers are required to master learning techniques using ICT (Information Communication Technology). e. Students who do not have high learning motivation tend to fail.

Likewise, the opinion of Syamsul Arifin (2020), that online learning cannot be optimal in facilitating the realization of one of the important aspects of education, namely the formation of attitudes, especially for high levels such as the classical theory of education from Benjamin S. Bloom with characterization.

The results of our preliminary research at PKBM AL Islah, Central Jakarta, show that generally educators are only fixated on formal curriculum guidelines and do not take advantage of other factors (hidden curriculum) other than those that have been set. Cas wita, (2013:8) states that most educators do not know that the hidden curriculum is very important in learning, they only pay attention to the core curriculum, even though in reality the hidden curriculum has a positive impact on learning. influenced by the hidden role of the curriculum because educators can easily translate social and moral messages through unconscious attitudes. Hidden 


\section{Implementation of Hidden Curriculum in Online Learning at PKVM Al Ishlah Central Jakarta}

curriculum according to Smith (1991: 258) does not emphasize content but on meaning-full. Learning that pays attention to the hidden curriculum is closely related to the formation of strong character values.

In general, an educator with good character will also have difficulty transmitting character values even through various techniques and methods. Therefore, educators need to find the right form of online learning to meet the demands of the formal curriculum while at the same time implementing the hidden curriculum properly without reducing its role in building the character of students.

Therefore, researchers are interested in examining how the implementation of the hidden curriculum is carried out by teachers in shaping the character of students in online learning during the covid-2019 pandemic in the PKBM AL Ishlah Package C Package Program, Central Jakarta.

\section{THEORITICAL REVIEW}

\section{A. Hidden Curriculum Basic Concepts}

The definition of curriculum in Law Number 20 of 2003 concerning the National Education System Article 1 point 19 is: "The curriculum is a set of plans and arrangements regarding the objectives, content, and learning materials as well as the methods used as guidelines for the implementation of learning activities to achieve certain educational goals. Michaels, Grossman and Scott as quoted by Toenlie which states: "The planned curriculum is defined as broad goals and specific objectives, content, learning activities, use of instructional media, teaching strategies, and evaluation stated, planned and carried out by school personal ". Based on the description above, the curriculum is defined as an educational program that contains various teaching materials and learning experiences that are programmed, planned and systematically designed on the basis of applicable norms. The curriculum has a central position in any educational endeavor (Klein, 1989:15).

The functions of the curriculum for educators are; (https:/www.dosen Pendidikan.co.id/pengertian-kurikulum-menurut-paraahli/

- Working guidelines in compiling and organizing students' learning experiences.

- Guidelines for conducting an evaluation of the development of students in order to absorb a number of experiences provided.

The curriculum according to Sukiman, (2015), in his book Development of Higher Education Curriculum includes a very broad understanding including potential curriculum, actual curriculum, and hidden curriculum. The potential curriculum or ideal curriculum is a written plan or program, which is a guide for educators in carrying out learning activities. Wina Sanjaya, (2019) in her book Curriculum and Learning, says that: Every educator should be able to carry out activities according to the demands of the curriculum because the ideal curriculum is a guide for educators, and the curriculum is called the formal curriculum or written curriculum. The actual curriculum is a curriculum that is factually implemented by educators according to existing conditions .

The hidden curriculum is an activity in the Package C Program that also influences the development of students, but is not programmed in the ideal curriculum curriculum. According to Sukiman, (2015), hidden curriculum (hidden curriculum) in his book Development of Higher Education Curriculum, are things or activities that occur in schools and influence the development of students, but are not programmed in the potential/ideal curriculum. Regarding the hidden curriculum, Kohelberg in Dakir (2019), said that the hidden curriculum is related to moral education and the role of educators in transforming moral standards. Hidden curriculum occurs in the interaction process of teachers, students, class structures, overall organizational patterns and so on in a school relationship. Learning as a process of interaction between teachers, students and materials, is often unknowingly "learned" by students, even though it is not planned, and because of that it is often neglected so that it escapes the attention of the teacher. This is what the hidden curriculum says. This means that the hidden curriculum appears as a side effect of the interaction between students, teachers and the material and learning environment.

\section{B. Character Building of Students}

The term character is taken from the Greek "Charassian" which means "to mark" or to mark and focus on how to apply the value of goodness in the form of actions or behavior, so that people who are dishonest, cruel, greedy and other bad behavior are said to have bad character. On the other hand, people whose behavior is in accordance with moral rules are called noble characters.

Character according to Michael Novak based on Thomas Likona (2012), says that character is "a compatible mixture of all the virtues identified by religious traditions, literary stories, sages, and common sense people in history." Character formation has the same orientation as moral education. Character education according to Zubaedi (2012: 19) is all business planning carried out by teachers that can affect the formation of the character of their students, understand, shape, and foster ethical values as a whole.

Furthermore, according to Wibowo (2013: 40) character education is an education that is used to instill and develop character in students, so that they have noble character after having them can apply it in everyday life like at home, at school and in the community. In the implementation of character education or moral education, an educator has full responsibility in guiding and setting an example for students from an early age so that they are accustomed to respecting their parents, family, teachers and friends.

In shaping the quality of good character values, educators need to guide students with the right method. The character education method is an effort that is carried out systematically by educators in order to create positive quality values for children's characters. According to Uswatun Hasanah, quoting the opinion of Doni Koesoema (https://media.neliti.com/media/publications/56629-ID- 


\section{Implementation of Hidden Curriculum in Online Learning at PKVM Al Ishlah Central Jakarta}

model-model- Pendidikan-character.pdf) some of the methods of character education are: (1) Teaching; ..... teaches character education in order to introduce theoretical knowledge about value concepts. (2) exemplary; consistency in teaching character education is not just through what is said through learning in the classroom, but it also appears in the teacher, in real life outside the classroom. The character of the teacher determines the color of the personality of the students. (3) determine priorities; educational institutions have priorities and basic demands on the character they want to apply in their environment. Character education collects many sets of values that are considered important for the implementation and realization of the vision of educational institutions. Therefore, educational institutions must determine the standard demands for the characters offered to students as part of institutional performance. (4) priority practice; Another very important element for character education is evidence of the implementation of the priority values of character education. In relation to the demands of educational institutions on the priority values that become the vision of their educational performance, educational institutions must be able to verify the extent to which the school's vision has been able to be realized within the scope of scholastic education through various elements within the institution. (5) reflection; The character that will be formed by educational institutions through various programs and policies always needs to be evaluated and reflected on continuously and critically. (Jamal Makmur

Asmani 2008, 67-70)

Improving the quality of students at all stages and levels of education cannot be separated from efforts to build positive and strong characters both in the school education environment, as well as in non-formal and informal education environments. Character education has a very useful function for a person, as explained by Salahudin and Alkrienciechie (2013: 43) the function of character education is as follows: 1. Develop basic potential to behave well. 2. Reinforce good behavior and can correct bad behavior. 3 . Helping to be able to filter out foreign cultures that are not in accordance with the values of Pancasila.

In this regard, it is clear that a hidden curriculum or a hidden curriculum can be implanted through the entire education process. Muchlas Samami and Hariyanto (2013) mention that the cultivation of character values can be done through learning activities by implementing a hidden curriculum.

\section{Indicators of Character Formation of Students}

In forming the character of students, there are character education values according to the Ministry of Education and Culture (2013), namely:

1. Religious. Obedient attitudes and behavior in carrying out the teachings of the religion they adhere to, being tolerant of the implementation of worship of other religions, and living in harmony with adherents of other religions.

2. Be honest. Behavior based on efforts to make himself a person who can always be trusted in words, actions, and work.

3. Tolerance. Attitudes and actions that respect differences in religion, ethnicity, ethnicity, opinions, attitudes, and actions of others who are different from themselves.

4. Discipline. Actions that show orderly behavior and comply with various rules and regulations.

5. Hard Work. Actions that show orderly behavior and comply with various rules and regulations. So with this orderly behavior can build student character in real life.

6. Creative. Thinking and doing something to produce a new way or result from something you already have.

7. Independent. Attitudes and behaviors that are not easy to depend on others to complete tasks.

8. Democratic. A way of thinking, behaving, and acting that evaluates the rights and obligations of himself and others.

9. Curiosity. Attitudes and actions that are always trying to find out more deeply and widely from something that is learned, seen, and heard.

10. National Spirit. A way of thinking, acting, and having insight that places the interests of the nation and state above the interests of themselves and their groups.

11. Love the Motherland. A way of thinking, acting, and having insight that places the interests of the nation and state above the interests of themselves and their groups.

12. Rewarding Achievement. Attitudes and actions that encourage him to produce something useful for society, and recognize, and respect the success of others.

13. Friendly/Communicative. Attitudes and actions that encourage him to produce something useful for society, and recognize, and respect the success of others.

14. Peaceful Love. Attitudes and actions that encourage him to produce something useful for society, and recognize, and respect the success of others.

15. Likes to Read. Habits of taking time to read various readings that give virtue to him.

16. Care for the Environment. Attitudes and actions that always try to prevent damage to the surrounding natural environment, and develop efforts to repair it. This is very important considering that students often interact with the surrounding community.

17. Social Care. Attitudes and actions that always want to help other people and communities in need.

18. Responsibility. That is the attitude and behavior of a person to carry out his duties and obligations, which he should do, towards himself, society, the environment (nature, social and culture), the state and God Almighty. 


\section{Implementation of Hidden Curriculum in Online Learning at PKVM Al Ishlah Central Jakarta}

\section{METHOD}

This study uses a naturalistic phenomenological qualitative approach with the aim of understanding and interpreting the meaning of the interaction of educator behavior in depth about the application of the hidden curriculum in shaping the character of students in online learning at PKBM Al Ishlah, Central Jakarta. Taking research subjects using the snowball technique, which according to Agus Salim (2006:13) "samples are taken from key informants, then added and expanded according to the first sample information and so on. The determination of key informants was done intentionally, then if in data collection there was no longer any variation in information found, then the researcher no longer needed to look for new informants, because the information collection process was considered complete. This research method is descriptive method. Data processing uses in-depth interview techniques (dept interview), observation, and documentation. Data analysis, namely qualitative data analysis, is more focused during the process of activities in the field along with data collection, and after completing data collection within a certain period (Sugiyono, 2012: 245). The steps taken in data analysis are data collection (data collection), data simplification (data reduction), data presentation (data display), and conclusion and verification (conclusion; drawing/verifying).

\section{RESULTS}

PKBM Al Islah Central Jakarta has a commitment to always improve the quality and competence of its human resources so as to create a good learning environment. Conditions in PKBM there are 14 tutors / educators who have qualified competence with Bachelor qualifications there are 6 people and Masters there are 2 people. Student activities, both academic and non-academic, are always well organized to develop the talents, interests and creativity of students. For example: religion, sports and the arts.

Character formation includes the introduction of online learning. According to the tutor, it is carried out through a hidden curriculum which is expected to develop religious, disciplined, polite, caring, and participatory characters. The hidden curriculum in this case the content is not as learning material, but the emphasis is as an inculcation of attitudes, policies, and appropriate environmental arrangements. Examples can be seen in the following table.

Table 1. Character Shapes in Online Learning Preliminary Activities

\begin{tabular}{|c|c|c|c|}
\hline No. & Aspect & Indicator & Sub-Indicator \\
\hline \multirow[t]{5}{*}{1} & $\begin{array}{l}\text { Activity Introduction } \\
\text { Learning }\end{array}$ & Religious & $\begin{array}{l}\text { 01. Advise to say hello at the time of meeting } \\
\text { 02. It is recommended to recite a prayer before studying } \\
\text { 03. Advise to pray for students who are sick / unable to attend } \\
\text { 04. Advise to visit sick students } \\
\text { 05. Advise to say the word alhamdulillah after learning }\end{array}$ \\
\hline & & Discipline & $\begin{array}{l}\text { 06. Checking the learning link before starting to study } \\
\text { 07.Start online learning on time } \\
\text { 08. Learn online according to the time allocated } \\
\text { 09. Checking student attendance online learning } \\
\text { 10. End online learning on time }\end{array}$ \\
\hline & & Polite & $\begin{array}{l}\text { 11. Saying greetings via online messages with good voice and sentences } \\
\text { 12. Greet students via online messages } \\
\text { 13. Inquire via online messages }\end{array}$ \\
\hline & & Social Care & $\begin{array}{l}\text { 14. Asking about readiness to start studying } \\
\text { 15. Checking student learning engagement } \\
\text { 16. Inquire about student absence } \\
\text { 17. Helping friends who have learning difficulties }\end{array}$ \\
\hline & & Participatory & $\begin{array}{l}\text { 18. Give a chance to ask questions } \\
\text { 19. Provide opportunities to answer questions } \\
\text { 20. Provide opportunities for student involvement in learning }\end{array}$ \\
\hline
\end{tabular}

The formation of the character of students in the core learning activities can be directed to independence, logical thinking, creative, cooperation, hard work, mutual respect, care for the environment, and self-confidence. For example as follows. 


\section{Implementation of Hidden Curriculum in Online Learning at PKVM Al Ishlah Central Jakarta}

Table 2. Character Shapes in the Core Activities of Online Learning

\begin{tabular}{|c|c|c|c|}
\hline No. & Aspect & Indicator & Sub-Indicator \\
\hline 1 & $\begin{array}{ll}\text { Core } & \text { activities } \\
\text { Learning } & \end{array}$ & $\begin{array}{l}\text { Creative and } \\
\text { independent }\end{array}$ & $\begin{array}{l}\text { 01. Rewarding a creative behavior } \\
\text { 02. Giving appreciation to students' creative work } \\
\text { 03. Encourage students to work independently } \\
\text { 04. Try your own decision-making skills } \\
\text { 05. Remind not easily influenced by others } \\
\text { 06. Provide opportunities for various learning activities }\end{array}$ \\
\hline & & $\begin{array}{c}\text { Think } \\
\text { Logically }\end{array}$ & $\begin{array}{l}\text { 07. Encouraging students to increase their enthusiasm for learning } \\
\text { 08. Encourage students to get used to thinking correctly } \\
\text { 09. Promote problem solving skills } \\
\text { 10. Encourage students to seek answers to learning problems }\end{array}$ \\
\hline & & $\begin{array}{l}\text { Cooperation } \\
\text { and Mutual } \\
\text { Respect }\end{array}$ & $\begin{array}{l}\text { 11. Encourage students to participate in discussions } \\
\text { 12. Advise to work with fellow friends } \\
\text { 13. Encourage respect for friends' opinions during discussions } \\
\text { 14. Advise to accept other people's opinion } \\
\text { 15. Advise greetings when meeting each other } \\
\text { 16. Advise saying sorry and thank you }\end{array}$ \\
\hline & & $\begin{array}{l}\text { Environmental } \\
\text { Care }\end{array}$ & $\begin{array}{l}\text { 17. Advise to keep the house and environment clean } 18 . \\
\text { Encourage energy-saving habits }\end{array}$ \\
\hline
\end{tabular}

Character formation in the closing activities of online learning is directed to the formation of various characters, for example critical, honest, confident, responsible, and religious.

Table 3. Character Shapes in Closing Activities of Online Learning

\begin{tabular}{|l|l|l|l|}
\hline No. & Aspect & Indicator & Sub-Indicator \\
\hline 1 & $\begin{array}{l}\text { Activity } \\
\text { Learning }\end{array}$ & $\begin{array}{l}\text { Critical } \\
\text { Thinking }\end{array}$ & $\begin{array}{l}\text { 01. Lets observe the learning outcomes obtained } 02 . \\
\text { Suggest solving individual/group problems. } \\
\text { 03. Provide an opportunity to ask questions at the end of study }\end{array}$ \\
\hline & & Honest & $\begin{array}{l}\text { 04.Mendorong untuk mematuhi perintah/petunjuk guru } \\
\text { 05. Mengajak siswa selalu berkata dan bertingkah laku jujur } \\
\text { 06. Menganjurkan siswa untuk mengerjakan tugas sendiri }\end{array}$ \\
\hline & & Responsibility & $\begin{array}{l}\text { 07. Remind to complete the task completely } \\
\text { 08. Advise to take individual tests }\end{array}$ \\
& & Religious & $\begin{array}{l}\text { 09. Encourage students to read prayers when they finish studying } \\
\text { 10. Give a message to always study well } \\
\text { 11. Set a good example for students }\end{array}$ \\
\hline
\end{tabular}

\section{ANALYSIS AND DISCUSSION OF RESEARCH RESULTS}

Researchers analyzed as follows: Character formation in preliminary learning activities. In preliminary learning activities, the implementation of a hidden curriculum in the formation of the character of students through online learning is directed at certain characters that allow students to do this.

The curriculum is important in achieving quality education. It is explicitly stated by Klein, (1989:15) that the curriculum has a central position in every educational effort. The curriculum in this study is mainly a hidden curriculum that focuses on character education. The hidden curriculum plays a strategic role in carrying out character education. Therefore, this hidden curriculum is not programmed in the formal curriculum but plays a strategic role in transforming moral standards. This is in accordance with the opinion of Sukiman, (2015), in his book Development of Higher Education Curriculum, that hidden curriculum are things or activities that occur in schools and influence the development of students, but are not programmed in the potential/ideal curriculum. . Regarding the hidden curriculum, Kohelberg in Dakir (2019), said that the hidden curriculum is related to moral education and the role of educators in transforming moral standards. Hidden curriculum occurs in the interaction process of teachers, students, class structures, overall organizational patterns and so on in a school relationship. Learning as a process of interaction of teachers, students and material, is often unwittingly "learned" by students, even though it is not planned, and because it is often neglected so that it escapes the attention of educators. Students, even though it is not planned, and because it is often neglected so that it escapes the attention of the teacher. 


\section{Implementation of Hidden Curriculum in Online Learning at PKVM Al Ishlah Central Jakarta}

The formation of the character of students through online learning at the opening of the learning includes religious, disciplined, polite, social care, and participatory characters. Through online learning, educators who try to form religious characters have gotten used to greeting students before learning activities begin both orally and in writing which are integrated with work sheets or assignments given to students. Greetings that are accustomed to by teachers are not only during learning activities, but are something that educators are accustomed to doing every time they interact with students whenever and wherever including outside learning activities.

Character education is closely related to hidden curriculum. This is in line with Zubaedi's (2012:19) opinion, namely all business plans carried out by tutors that can affect the formation of the character of their students, understand, shape, and foster ethical values as a whole. One method is habituation. Another habit that is always done by the teacher is to encourage students to get used to reading prayers to start and end learning which is carried out both individually and together, including inviting students to get used to always helping and giving good prayers to others. his colleagues so that they can overcome the learning problems they face, and prayers for healing if there are other colleagues who are sick which causes them to be unable to participate in learning activities. Character education functions as an effort to build the mental qualities of students to be positive and strong. It is expressly stated by Salahudin and Alkrienciechie (2013:43) that the function of character education is as follows: 1. Develop basic potential for good behavior. 2. Reinforce good behavior and can correct bad behavior. 3. Helping to be able to filter out foreign cultures that are not in accordance with the values of Pancasila. The formation of the character of other students is the character of discipline, where educators at PKBM every time they start online learning have gotten used to first conveying messages to students that learning is carried out on time as set out in the lesson schedule. Educators also always convey information about the allocation of time used to carry out learning activities whose length is in accordance with the learning load imposed for students in PKBM. Then to make students more orderly in participating in online learning, the teacher always checks the participation and involvement of students in their daily notes. Likewise, teachers have tried to make students have an attitude and behavior that is always orderly and obedient to the rules and regulations. The formation of the character of other students is the character of courtesy, the tutors interact with their students, especially when online learning begins, through oral or written messages they always get used to greeting students about their learning readiness with polite words, even always getting used to inquire about their whereabouts, about their study activities, their health, and sometimes inquiring about their family wisely.

Various character values are built and developed through the hidden curriculum function. This is in accordance with the opinion expressed by the Ministry of Education and Culture (2013) that character values built through education are 1. Religious; 2 . Honest; 3. Tolerance; 4. Discipline; 5. Hard Work; 6. Creative; 7. Independent; 8. Democratic; 9. Curiosity; 10. National Spirit; 11 . Love of the Motherland; 12. Rewarding Achievements; 13. Friendly/Communicative; 14. Peaceful Love; 15. Likes to Read;

16. Care for the Environment; 17. Social Care; 18. Responsibility.

Character formation as the values stated above, the students are polite character, the tutors before starting online learning have gotten used to asking about the readiness of students. Tutors pay attention to the involvement and participation of students in learning, because it is feared that some of them might forget the study schedule so that they do not take part in learning activities. If any of them do not take lessons, the tutors always ask why and what difficulties are causing them not to take lessons, even educators always encourage students to get used to helping each other if some of their friends have learning difficulties.

The formation of other students' character is participatory character, where tutors in online learning have become accustomed to giving students the opportunity to ask students things related to the material before learning begins. In addition, tutors provide opportunities for students to answer questions posed by educators or their peers before online learning activities begin. Of all the habits mentioned above by tutors, it is an effort made to shape the various characters of students through the implementation of a hidden curriculum through online learning during the COVID-19 pandemic which was carried out in preliminary learning activities. Character formation in the core learning activities of hidden curriculum implementation in the formation of students' character through online learning during the COVID-19 pandemic carried out by tutors, including creative and independent characters, logical thinking, cooperation and mutual respect, caring for the environment, and self-confident. In forming creative characters for students, tutors always instill an attitude of creativity through the formation of the creative character of their students by trying to provide consistent treatment in the form of awards, recognition, praise, for their creative work. Students who consistently receive proportional recognition and appreciation for their work, especially those of creative value, feel that they have a place for their achievements, and all of this can foster self-confidence and a positive self-concept. Likewise, tutors in forming independent characters always try to develop themselves by their students when completing individual tests or assignments. The selfdevelopment given by the teacher is in the form of an appeal when students do tests or individual assignments, so that they can be done independently without seeing the work of other friends, and can create them when the test or task is completed. In addition, teachers provide opportunities for students to get used to being able to solve problems on their own independently well without the help of others. This is in accordance with the self-development program carried out through character building which is integrated into everyday learning at school, including getting used to making their own decisions in solving learning problems.

In forming the character of logical thinking for students, educators recommend students to always increase the spirit of learning, get used to thinking correctly in understanding the subject matter, and trying to find their own answers to the learning problems they 


\section{Implementation of Hidden Curriculum in Online Learning at PKVM Al Ishlah Central Jakarta}

face, because logical thinking is a form of ability. think students in understanding the lesson correctly. Formation of cooperative character for students, educators always try to encourage students to participate in discussions, help each other among group members in solving learning problems, even among group members and even friends to work together by sharing knowledge. In addition, educators always encourage their students to always get used to working together in learning with other friends. When studying together they are encouraged to respect and accept the opinions of other friends, advise them not to look down on others, greet other friends when they meet each other, and recommend saying sorry if there is a mistake against other friends, as well as thanking others. friend who has been kind to him.

In shaping the character of caring for the environment for students, educators through online learning, educators always provide examples and appeal to participants to become clean, tidy, friendly, and independent individuals. Students are expected to be clean, tidy, friendly, and independent individuals through the appeals and advices given by the teachers, for example getting used to always cleaning their own learning places both before and after online learning takes place, including an appeal to always get used to using facilities and equipment. learning infrastructure effectively and efficiently.

The formation of self-confident character for students, tutors hone students' self-confidence by getting used to praising their students and giving appreciation to everything that students do, whether it's good or still not good. If there is criticism to be conveyed, the teachers start with a compliment which is added with direction in the hope that the criticism can be more easily accepted by the children, including providing motivational words in all aspects, learning motivation or other motivations that can improve their talents, so they believe if they dare try to reap positive results. Of all the habits mentioned above by tutors, it is an effort made in order to shape the various characters of students through the implementation of a hidden curriculum through online learning during the COVID-19 pandemic which is carried out in core learning activities.

Character formation in the closing activities of learning. In the closing activity of online learning activities, the implementation of a hidden curriculum (hidden curriculum) in shaping the character of students through online learning during the COVID-19 pandemic carried out by tutors includes the characters of logical, honest, responsible, and religious thinking. The formation of logical thinking characters for students, tutors always provide opportunities for them to re-correct the learning outcomes they get. This teacher gives many assignments in the form of cases that they have to solve either individually or in groups, including solving problems on paper. In addition, discussions between children can create a dialogue between them. In addition, teachers have made various efforts to instill the character of critical thinking in students even though they receive and absorb subject matter in relatively different understandings. In forming honest characters for students, tutors always remind their children to obey and carry out teacher orders regarding online learning. Children are expected not to cheat in doing assignments or exams, because these actions allow the teacher to give punishment by reprimanding students so that it can have a deterrent effect. In addition, teachers have tried to shape them so that they have attitudes and behaviors that can always be trusted in words, actions, and other work. This is in accordance with the objectives of character education launched by the government to instill character values in students.

The formation of the character of responsibility for students, teachers in the implementation of this character can be seen when students can be relied on when doing assignments. As well as carrying out tasks in accordance with the rules or agreements, working with the group, including being responsible for all the actions he takes. In addition, they work on assignments and exercises which then submit them on time according to the mutually agreed rules. Tutors who are role models for their students, teachers also play a role in getting used to the habits of students in carrying out their duties in accordance with the agreed rules.

In shaping the religious character of students, the teachers of SDN Mugarsari through online learning, students always try to have a religious attitude, namely by regularly reading prayers both individually and together before and after online learning is carried out. In addition, teachers always encourage students to say hello to them before going home from school, and provide good examples to all students. Of all the habits mentioned above by tutors, it is an effort made to shape the various characters of students through the implementation of a hidden curriculum through online learning during the COVID-19 pandemic which is carried out in core learning activities.

\section{CONCLUSIONS}

Referring to the results of the research and analysis as well as the discussion above, the conclusions are:

a. The tutors at PKBM Al Ishlah implement a hidden curriculum in preliminary learning activities, have gotten used to instilling the values of values of religious character, discipline, politeness, social care, and participation, through messages delivered together in the online study guide.

b. Tutors at PKBM Al Ishlah in implementing the hidden curriculum through core learning activities, have accustomed themselves to instilling value independent character, cooperation, care for the environment, and self-confidence, through messages delivered together in the online study guide.

c. Mugarsari Elementary School teachers in implementing the curriculum hidden through preliminary learning activities, have gotten used to instilling character values of critical, honest, responsible, and religious thinking through messages delivered simultaneously in online learning guides. 


\section{Implementation of Hidden Curriculum in Online Learning at PKVM Al Ishlah Central Jakarta}

\section{SUGGESTION}

a. The awareness of students needs to be increased again by motivating them to be more active in participating in planned online learning activities by the school.

b. Teacher competencies need to be improved so that their competencies can be optimize their role as educators and mentors more creatively who always try to apply various strategies in carrying out their duties learning.

c. Equip school facilities and infrastructure so that online learning can be implemented as expected, especially in supporting successful implementation of the hidden curriculum in the future covid-19 pandemic.

\section{ACKNOWLEDGMENT}

We would like to thank the Institute for Research and Community Service - State University of Jakarta (LPPM UNJ) which has funded this research

\section{REFERENCES}

1) Caswita. (2019). The Hidden Curriculum: The Study of PAI Learning in Schools. Yogyakarta: PT Leutikaprio.

2) Dakir. (2019). Curriculum Planning and Development. Jakarta: PT Rineka Cipta.

3) Rosyada, D. (2004). Democratization of Curriculum Development in Schools (Journal).

4) Lickona, T. (2017). Character Education Book. Bandung: PT Nusa Media.

5) Samami, M. \& Hariyanto. (2013). Character Education Concepts and Models. Bandung: Rosdakarya Youth.

6) Ministry of National Education. (2010). Development of National Culture and Character Education: School Guidelines. Jakarta: Balitbang.

7) Lickona, T. (2012). Educating To Build Character: How Schools Can Provide Education About Respect And Responsibility. Juma Abdu Wamaungo translation. Jakarta: PT Bumi Aksara.

8) Lickona, T. (2013). Educating for Character How Our Schools Can Teach Respect and Responsibility. Jakarta: Earth Literacy, Translation of Juma Abdu Wamaungo.

9) National Education System. (2003). Regarding the National Education System Law No. 20 of 2003.

10) Rahayu, S., et al. (2020). Independent Learning: Online Learning in the Midst of the Covid-19 Pandemic North Sumatra: Our Writing Foundation.

11) Sukiman. (2015). Higher Education Curriculum Development. Bandung: PT Pemuda Rosdakarya.

12) Sugiyono. (2012). Qualitative Quantitative Research Methods and R\&D. Bandung: Alphabeta.

13) Arifin, S. (2020). Online Learning as An Anomaly. Surabaya: Jawa Pos newspaper.

14) Sanjaya, W. (2019). Curriculum and Learning. Jakarta: Prenada Media Group 